\title{
Dural Invasion and Proliferative Potential of Pituitary Adenomas
}

\author{
Go DAITA and Yukichi YONEMASU
}

\author{
Department of Neurosurgery, Asahikawa Medical College, Asahikawa, Hokkaido
}

\begin{abstract}
The relationship between invasiveness and proliferative potential was studied in 31 cases of pituitary adenomas. The invasiveness was determined by histological examination of sellar floor dura resected during transsphenoidal surgery. The proliferative potential of adenoma specimens was examined immunohistochemically using monoclonal antibody (MIB-1). There were 11 adenomas with histologically verified dural invasion out of 31 cases. These adenomas had a higher MIB-1-positive ratio than adenomas without dural invasion $(\mathrm{p}<0.05$ ). Pituitary adenomas with a high proliferative potential tend to be invasive.
\end{abstract}

Key words: dura mater, neoplasm invasiveness, pituitary neoplasm, proliferative cell nuclear antigen

\section{Introduction}

Invasive pituitary adenomas were previously thought to be rare. ${ }^{3)}$ However, more recent studies have found that invasion of pituitary adenomas into the cavernous sinus is not uncommon and invasion into the dura of the pituitary fossa is frequent. ${ }^{15}$ ) Histological studies of surgical specimens of pituitary adenomas have verified that dural invasion is common. ${ }^{7,9,14)}$

Magnetic resonance (MR) imaging has been used in many studies on the clinical diagnosis of invasion into the cavernous sinus, but the criteria still remain controversial..$^{4,8,11,13)}$ We previously reported a positive relationship between MR imaging of cavernous sinus invasion and histologically verified dural invasion of the sellar floor. ${ }^{1)}$

Here, we report the relationship between histologically verified dural invasion and the proliferative potential of pituitary adenomas.

\section{Materials and Methods}

Thirty-one specimens of pituitary adenomas and dura from the sellar floor were resected by transsphenoidal surgery at Asahikawa Medical College Hospital between March 1986 and June 1994. Classification of the adenomas was based on endocrine

Received June 5, 1995; Accepted October 11, 1995 analysis (Table 1). The height and width of each adenoma was measured on coronal MR images with gadolinium-diethylenetriaminepenta-acetic acid administration. The size of the adenomas was conveniently represented by multiplying the height by the width.

Specimens of pituitary adenomas and pieces of the sellar floor dura about $4 \mathrm{~mm}^{2}$ were embedded in paraffin after formalin fixation. After $4-\mu \mathrm{m}$ thick sections were prepared, the dura was stained with HE. The presence of a mass of adenoma cells in the dura was judged as a positive invasion of the pituitary adenoma (Fig. 1). The proliferative potential of the adenomas was estimated by an immunohistochemical method: unstained slides were prepared from paraffin-embedded samples, and antigen retrieval of adenoma tissue was performed by microwave irradiation. ${ }^{16)}$ The slide was stained using a monoclonal antibody (MIB-1; Immunotech S.A., Marseille, France). The cells were counted in nonhemorrhagic and less vascular areas containing more than 1000 cells, and the MIB-1-positive ratio was calculated (Fig. 2).

\section{Results}

Adenoma invasion into the dura was present in 11 of the 31 cases (Table 1). The MIB-1-positive ratio ranged from 0.58 to 3.72 (mean \pm SD $1.80 \pm 0.85$ ) in the 11 adenomas with invasion, and 0.26 to 2.02 
Table 1 Details of pituitary adenoma cases

\begin{tabular}{|c|c|c|c|c|c|c|c|}
\hline \multirow{2}{*}{$\begin{array}{l}\text { Case } \\
\text { No. }\end{array}$} & \multirow{2}{*}{$\underset{\text { Sex }}{\text { Age/ }}$} & \multirow{2}{*}{$\begin{array}{l}\text { Type of } \\
\text { adenoma }\end{array}$} & \multirow[b]{2}{*}{$\mathrm{H}(\mathrm{mm})$} & \multicolumn{2}{|c|}{ Extent of adenoma } & \multirow{2}{*}{$\begin{array}{l}\text { Dural } \\
\text { invasion* }\end{array}$} & \multirow{2}{*}{$\begin{array}{c}\text { MIB-1-positive } \\
\text { ratio }\end{array}$} \\
\hline & & & & $\mathrm{W}(\mathrm{mm})$ & Size $\left(\mathrm{H} \times \mathrm{W}, \mathrm{mm}^{2}\right)$ & & \\
\hline 1 & $44 / F$ & PRL & 29 & 17 & 493 & - & 2.02 \\
\hline 2 & $49 / \mathrm{M}$ & $\mathrm{GH}$ & 12 & 15 & 180 & - & 0.81 \\
\hline 3 & $34 / F$ & ACTH & 13 & 10 & 130 & - & 1.10 \\
\hline 4 & $39 / \mathrm{F}$ & $\mathrm{GH}$ & 28 & 17 & 476 & - & 0.81 \\
\hline 5 & $64 / M$ & non & 33 & 20 & 660 & - & 0.26 \\
\hline 6 & $49 / F$ & non & 27 & 25 & 675 & - & 0.38 \\
\hline 7 & $59 / \mathrm{F}$ & non & 44 & 26 & 1144 & - & 0.52 \\
\hline 8 & $44 / M$ & non & 48 & 26 & 1248 & - & 0.65 \\
\hline 9 & $46 / F$ & PRL & 30 & 25 & 750 & - & 0.70 \\
\hline 10 & $35 / \mathrm{M}$ & $\mathrm{GH}$ & 15 & 19 & 285 & - & 0.69 \\
\hline 11 & $35 / F$ & PRL & 11 & 7 & 77 & - & 0.49 \\
\hline 12 & $29 / \mathrm{F}$ & PRL & 9 & 9 & 81 & - & 0.96 \\
\hline 13 & $51 / \mathrm{M}$ & non & 37 & 20 & 740 & - & 0.39 \\
\hline 14 & $44 / M$ & PRL & 28 & 13 & 364 & - & 0.57 \\
\hline 15 & $60 / \mathrm{F}$ & FSH & 26 & 21 & 546 & - & 0.90 \\
\hline 16 & $54 / \mathrm{M}$ & ACTH & 22 & 25 & 550 & - & 0.69 \\
\hline 17 & $20 / \mathrm{F}$ & $\mathrm{ACTH}$ & 9 & 12 & 108 & - & 0.39 \\
\hline 18 & $18 / \mathrm{F}$ & PRL & 18 & 17 & 306 & - & 1.27 \\
\hline 19 & $78 / \mathrm{M}$ & non & 31 & 20 & 620 & - & 0.36 \\
\hline 20 & $50 / \mathrm{F}$ & non & 9 & 17 & 153 & - & 0.65 \\
\hline 21 & $28 / \mathrm{M}$ & PRL & 40 & 21 & 840 & + & 2.02 \\
\hline 22 & $68 / \mathrm{F}$ & FSH & 29 & 22 & 638 & + & 1.35 \\
\hline 23 & $67 / \mathrm{M}$ & PRL & 27 & 20 & 540 & + & 1.21 \\
\hline 24 & $45 / F$ & non & 23 & 15 & 345 & + & 3.72 \\
\hline 25 & $28 / F$ & $\mathrm{GH}$ & 25 & 20 & 500 & + & 2.03 \\
\hline 26 & $69 / \mathrm{M}$ & non & 39 & 18 & 702 & + & 1.80 \\
\hline 27 & $29 / \mathrm{M}$ & non & 35 & 27 & 945 & + & 1.62 \\
\hline 28 & $57 / \mathrm{F}$ & PRL & 30 & 32 & 960 & + & 0.58 \\
\hline 29 & $49 / F$ & non & 30 & 26 & 780 & + & 2.42 \\
\hline 30 & $59 / \mathrm{M}$ & PRL & 31 & 33 & 1023 & + & 2.17 \\
\hline 31 & $59 / \mathrm{F}$ & non & 21 & 46 & 966 & + & 0.93 \\
\hline
\end{tabular}

*Histologically verified dural invasion. ACTH: adrenocorticotrophic hormone-secreting adenoma, FSH: folliclestimulating hormone-secreting adenoma, $\mathrm{GH}$ : growth hormone-secreting adenoma, $\mathrm{H}$ : vertical length of adenomas on MR images, non: non-secreting adenoma, PRL: prolactin-secreting adenoma, W: width of adenomas in the sella turcica on Gd-DTPA-enhanced coronal MR images.

$(0.73 \pm 0.40)$ in the 20 adenomas without invasion. The difference in MIB-1-positive ratio between these two groups was statistically significant $(p<0.01)$ (Table 2). There was no significant difference in the height of adenomas between these two groups. However, the width and size were significantly different $(p<0.05)$ (Table 2$)$.

\section{Discussion}

There is no agreement on the definition of "invasive adenoma" among the many reports on the invasive nature of pituitary adenomas. We previously showed a positive relationship between MR imaging findings and histologically verified invasion into the sellar floor dura by adenoma cells, ${ }^{17}$ and therefore defined an "invasive (pituitary) adenoma" as a histologically verified adenoma invading the sellar floor dura in this study.

An investigation of cavernous sinus invasion based on operative findings in 365 cases showed that the overall rate of invasion into the cavernous sinus was $35 \%$, and that macroadenomas tended to invade more frequently than microadenomas. ${ }^{12)}$ Microscopic examination of surgical specimens has shown that dural invasion of pituitary adenomas occurs in about $64-85 \%$ of cases. ${ }^{7,9,14)}$ However, the conclusions of these studies disagree. Selman et al. ${ }^{14)}$ reported the 


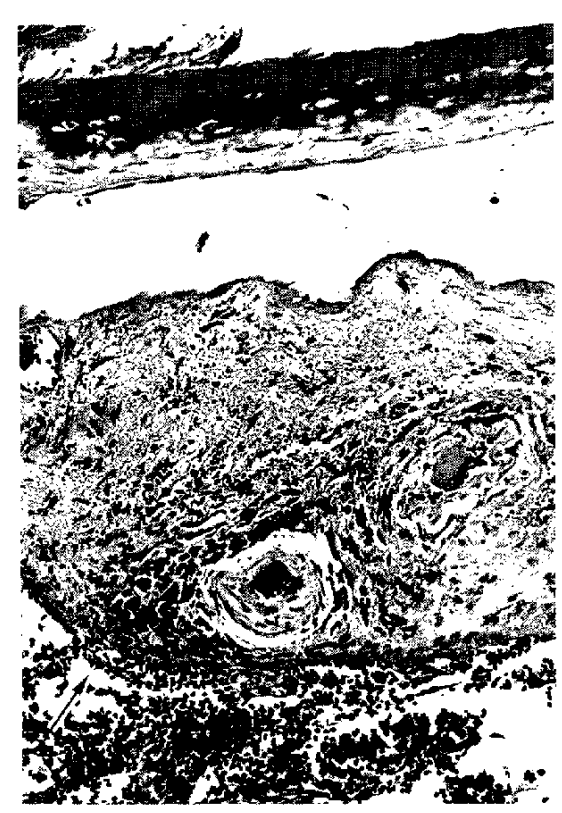

Fig. 1 Case 21. Photomicrograph revealing invasion of the dura by adenoma cells (arrow). The eroded sellar floor bone is in the upper field. HE stain, $\times 40$.

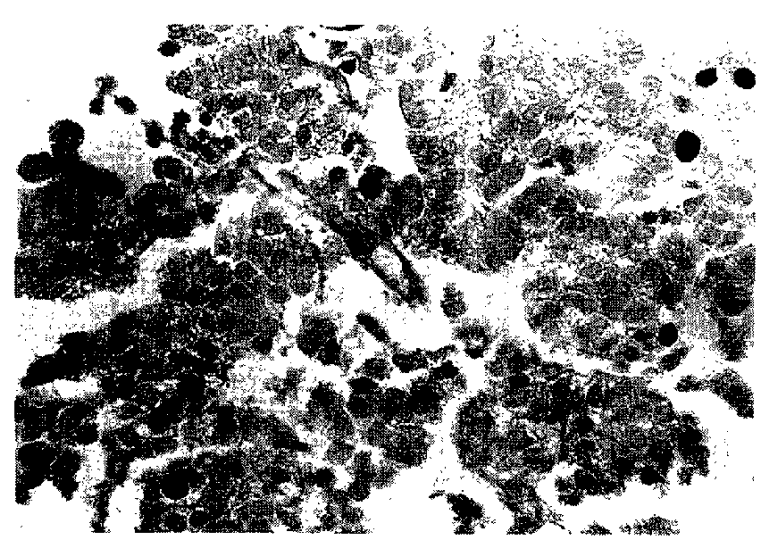

Fig. 2 Case 21. Photomicrograph showing the MIB1 -positive cells easily distinguished from negative cells. MIB-1 immunostain, $\times 200$. rate of dural invasion was higher in large adenomas than in smaller adenomas. In contrast, Knosp et al. ${ }^{\text {?) }}$ concluded that invasion was not related to the size of the adenomas. Our study found that the height of the adenomas was not significantly related to the dural invasion or MIB-1-positive ratio, but the width and size were significantly related. This may be due to the mode of extension of the adenoma in addition to the tumor proliferative activity. Presumably intrasellar growth due to a tough diaphragm is related to lateral extension and invasion of the dura and cavernous sinus, indicating that invasiveness of adenoma is multifactorial. In our study the occurrence of dural invasion was less frequent than reported in other studies, possibly due to differences in the histological diagnosis of invasion. Our diagnosis of invasion was based on the presence of an apparent adenoma cell island in the dura. Scattered cells along the dural fibers was not considered as invasion, because the diagnosis of these cells as adenoma cells is uncertain due to the size and appearance of the nuclei, or scanty cytoplasm.

There are few reports on the proliferative potential of pituitary adenomas. ${ }^{10,17)}$ Two investigations of the proliferative potential of pituitary adenomas with invasion into the sellar floor dura with histological verification, using $\mathrm{Ki}-67$ antibody for the evaluation of the growth fraction, demonstrated that invasive adenomas had higher values than noninvasive adenomas. ${ }^{6,9)} \mathrm{Kitz}$ et al. ${ }^{6)}$ only counted Ki-67-positive cells in areas where the positive cells were concentrated, which may be the reason why their proliferation rate (1.56) was slightly higher than that $(0.97)$ reported by Landolt et al. ${ }^{9)}$

Our study used MIB-1, which reacts to the Ki-67 nuclear antigen appearing in cell proliferation, so is equivalent to Ki-67 antibody. ${ }^{5}$ However, the MIB-1 is superior to $\mathrm{Ki}-67$ antibody because it can be applied to paraffin-embedded samples, whereas only frozen sections can be used for $\mathrm{Ki}-67$, and positive cells are easy to determine. Proliferative cell nuclear antigen (PCNA) is another antibody which can be used to count proliferative cells using paraffin-embed-

Table 2 Analysis of adenomas with vs. without invasion

\begin{tabular}{lccccc}
\hline & $\begin{array}{c}\text { No. of } \\
\text { cases }\end{array}$ & $\begin{array}{c}\text { MIB-1-positive } \\
\text { ratio }\end{array}$ & H (mm) & W $(\mathrm{mm})$ & Size $\left(\mathrm{H} \times \mathrm{W}, \mathrm{mm}^{2}\right)$ \\
\hline Without invasion & 20 & $0.73 \pm 0.40$ & $23.95 \pm 5.93$ & $18.05 \pm 4.23$ & $479.30 \pm 334.97$ \\
With invasion & 11 & $1.80 \pm 0.85^{* *}$ & $30.00 \pm 9.21$ & $25.45 \pm 8.08^{*}$ & $749.00 \pm 223.11^{*}$ \\
\hline
\end{tabular}

Growth rate, height, width, and size are shown as mean $\pm \mathrm{SD} .{ }^{*} \mathrm{p}<0.05,{ }^{* *} \mathrm{p}<0.01$ : statistically significant difference between the groups. 
ded samples, but the stained nuclei are variable in density. ${ }^{2)}$ Therefore, the ratio of positive cells by PCNA tends to vary between studies. MIB-1 is therefore superior to PCNA for the recognition of proliferating cells.

Our study showed a clear relationship between dural invasion and proliferative potential of pituitary adenomas, although there were a few exceptions. Invasiveness and the width and size dimensions of pituitary adenomas were significantly related, but the height was not. Further investigation on the proliferative potential and other factors related to the invasive nature of pituitary adenomas is needed.

\section{Acknowledgments}

The authors thank Miss Junko Takahashi for her technical assistance and Mr. Hironari Isobe for assistance in statistical analysis.

\section{References}

1) Daita G, Yonemasu Y, Nakai H, Takei H, Ogawa K: Cavernous sinus invasion of pituitary adenomas. Relationship between magnetic resonance imaging findings and histologically verified dural invasion. Neurol Med Chir (Tokyo) 35: 17-21, 1995

2) Galand P, Degraef C: Cyclyn/PCNA immunostaining as an alternative to tritiated thymidine pulse labelling for marking $\mathrm{S}$-phase cells in paraffin sections from animal and human tissues. Cell Tissue Kinet 22: 383-392, 1989

3) Jefferson J: Extrasellar extensions of pituitary adenomas. Proc $R$ Soc Med 33: 433-458, 1940

4) Kaufman B, Kaufman BR, Arahar BM, Roesmann Y, Selman WR: Large pituitary gland adenomas evaluated with magnetic resonance imaging. Neurosurgery $21: 540-546,1987$

5) Key G, Becker MHG, Duchrow M, Schulter C, Gerdes J: New Ki-67 equivalent murine monoclonal antibodies (MIB 1-3) prepared against recombinant parts of the Ki-67 antigen. Anal Cell Pathol 4: 181, 1992

6) Kitz K, Knosp E, Koos WTH, Korn A: Proliferation in pituitary adenomas. Measurement by MAb Ki 67. Acta Neurochir Suppl (Wien) 53: 60-64, 1991
7) Knosp E, Kitz K, Steiner E: Pituitary adenomas with parasellar invasion. Acta Neurochir Suppl (Wien) 53: $65-71,1991$

8) Komiyama M, Hakuba A, Yasui T, Yagura H, Fu Y, Baba M, Nishimura S: Magnetic resonance imaging of intracavernous pathology. Neurol Med Chir (Tokyo) 29: 573-578, 1989

9) Landolt AM, Shibata T, Kleihues P: Growth rate of human pituitary adenomas. J Neurosurg 67: 803806,1987

10) Nagashima T, Murovic JA, Hoshino $T$, Wilson $C B$, DeArmond SJ: The proliferative potential of human pituitary tumors in situ. $J$ Neurosurg 64: 588-593, 1986

11) Nichols DA, Laws ER Jr, Houser W, Abbound CF: Comparison of magnetic resonance imaging and computed tomography in the preoperative evaluation of pituitary adenomas. Neurosurgery 22: 380-385, 1988

12) Scheithauer BW, Kovacs KT, Laws ER Jr, Randall RV: Pathology of invasive pituitary tumors with special reference to functional classification. $J \mathrm{Neu}$ rosurg 65: 733-744, 1986

13) Scotti G, Yu CY, Dillon WP, Norman D, Colombo $\mathrm{N}$, Newton TH, Groot JD, Wilson CB: MR imaging of cavernous sinus involvement by pituitary adenomas. AJR Am J Roentgenol 151: 799-806, 1988

14) Selman WR, Laws ER Jr, Scheithauer BW, Carpenter SM: The occurrence of dural invasion in pituitary adenomas. $J$ Neurosurg 64: 402-407, 1986

15) Shaffi $O M$, Wrightson M: Dural invasion by pituitary tumors. $N Z$ Med J 81: 386-390, 1975

16) Shi SR, Key ME, Kalra KL: Antigen retrieval in formalin-fixed, paraffin-embedded tissues: An enhancement method for immunohistochemical staining based on microwave oven heating of tissue sections. $J$ Histochem Cytochem 39: 741-748, 1991

17) Shibuya M, Saito F, Miwa T, Davis RL, Wilson CB, Hoshino T: Histochemical study of pituitary adenomas with $\mathrm{Ki}-67$ and anti-DNA polymelase monoclonal antibodies, bromodeoxyuridine labeling, and nucleolar organizer region counts. Acta Neuropathol (Berl) 84: 178-184, 1992

Address reprint requests to: G. Daita, M.D., Department of Neurosurgery, Asahikawa Medical College, 4-5 Nishikagura, Asahikawa, Hokkaido 078, Japan. 